Research Article

\title{
Research and Application of Support Resistant Limiting Dampers in the Deep-Buried Large-Section Loess Tunnel
}

\author{
Yong Deng, Jiangsheng Xie, and Shuguang Li iD \\ China Railway 20th Bureau Group Co. Ltd., Xian 710016, China \\ Correspondence should be addressed to Shuguang Li; 1ssgg2015@163.com
}

Received 9 September 2020; Revised 17 September 2020; Accepted 18 September 2020; Published 30 September 2020

Academic Editor: Zhushan Shao

Copyright ( 2020 Yong Deng et al. This is an open access article distributed under the Creative Commons Attribution License, which permits unrestricted use, distribution, and reproduction in any medium, provided the original work is properly cited.

\begin{abstract}
The paper aims to solve the problem that the primary support of the deep-buried large-section loess tunnel of the Haolebaoji-Ji'an Railway was damaged due to excessive force. Based on indoor tests, on-site construction feedback, and monitoring measurement data, the surrounding rock deformation and structural forces with different support schemes were compared and analyzed. The engineering application methods and mechanism of the support resistant limiting damper (SRLD) technology were studied. The results show that for the deep-buried large-section loess tunnels, under the premise of ensuring the self-supporting capacity of the surrounding rock is not significantly reduced, and the loose pressure is not significantly increased, the resistance-limiting and high-ductility support concept that can control the deformation and the energy release of the surrounding rock is reasonable and feasible. The support resistant limiting damper (SRLD) is a reasonable and practical resistance-limiting and high-ductility support method, which successfully solved the failure of the primary support of the deep-buried large-section loess tunnel. The SRLD's integrity and safety are guaranteed, the materials are easy to obtain, the processing is convenient, and the construction is simple and easy to operate. The SRLD is a safe and economic support structure.
\end{abstract}

\section{Introduction}

With the development of transportation construction, more and more new tunnels need to traverse complex geology. Excavation and support problems caused by high ground stress, weak surrounding rocks, and other unfavourable geology have become the bottleneck of tunnel construction [1-3]. The special engineering characteristics of loess cause the loess tunnel large deformation during the excavation process [4], which brings challenges to theoretical research and design of the loess tunnel.

The colour of loess is from yellow to red-yellow; its bedding is not apparent; it is rich in carbonate, and it has a loose honeycomb-type metastable structure $[5,6]$. Li et al. [7] pointed out that the loess tunnel has large settlements at the arch and ground surface. It is recommended to adopt the seven-step method. Xue et al. [8] established the Delphi extended model to evaluate the deformation of the surrounding rock of the loess with a super-large section. The support structure with large rigidity can allow a small amount of deformation, and it is difficult to release the energy stored in the surrounding rock entirely, so the support problem is challenging to solve. In recent years, based on the concepts of energy absorption and energy dissipation in surrounding rocks, the "yield pressure support" or "flexible support" scheme has begun to be explored and implemented in scientific research and engineering. In the late 1990s, Kovári [9] pointed out that if the deformation of the surrounding rock is forcibly suppressed, it will cause excessive surrounding rock pressure, causing the internal force of the structure to exceed the bearing capacity. The only feasible support scheme in the construction of squeezing confining pressure tunnels is to allow the support structure to deform with the surrounding rock before failure and develop a "yield control" support concept. Anagnostou and Cantieni [10] pointed out that there are two ways to achieve yield control support: one is to fill the compressible layer behind the rigid support, which is more effective in the shield or TBM excavation support. The other way is to use the combination of a sliding steel frame and shotcrete, which 
can be sprayed when the sliding steel frame is deformed to a preset value or sprayed immediately after the steel frame is erected. At the same time, a "lining stress controller" [11] or "high compression concrete" [12] is inserted into the concrete at the sliding joint of the steel frame, so that the steel frame and the concrete can be compressed and deformed simultaneously. This kind of yield-controlled support has been widely used in tunnels such as Alpine Tunnel, Galgenberg Tunnel, Semmering Pilot Tunnel, and Saint MartinLa Porte Connection Channel [13-16]. Wu et al. [17-20] conducted a systematic theoretical study on the application of the yielding support concept in the tunnel support structure. Sun et al. [21] proposed an anchoring technology to control the continuous development of large deformations of the surrounding rock-a new type of large-scale letdown anchor rod. Wang et al. [22] started from the idea of the appropriate release of the deformation energy of surrounding rock and proposed a new design concept of timely strong-yield compression support. Based on this design concept, a pressure-relief support system is proposed.

At present, the pressure-relief and yield-controlled support technology are in the stage of theoretical research and summary of construction experience. There is no unified theoretical system and support plan. It is based on the "support resistant limiting dampers" (SRLDs) developed by Qiu et al. [23]. This paper focuses on its engineering application in the deformation control of deep-buried largesection loess tunnels, which provides a reference for the construction of similar tunnels in the future.

\section{Working Principle of Support Resistant Limiting Dampers (SRLDs)}

2.1. Energy Release Mechanism of Surrounding Rock. In the construction of high-energy geological environment tunnels, the surrounding rock often releases much energy after being disturbed. The primary support of the tunnel is the combination of bolts, steel frames, and shotcrete, and the deformation of these supports during the normal working phase is minimal. The small deformation of the primary support is difficult to fully release the large amount of energy stored in the surrounding rock, which brings a high surrounding rock pressure and causes the internal force of the primary support to exceed its ultimate bearing capacity.

When the primary support of the tunnel is cracked, the existing countermeasures mostly adopt the principle of "never weaker than strong" to strengthen support parameters. However, practice shows that merely increasing the support parameters cannot effectively solve the problem of primary support cracking $[24,25]$. The behaviour of the primary support with severe deformation and damage caused by repeated dismantling and replacement during construction is essentially the process of gradual deformation under certain constraints to release the deformation pressure of the surrounding rock. The cavern cannot stabilize until the pressure of the surrounding rock is released (see Figure 1). Therefore, in the high-energy geological environment, the tunnel construction should not adopt the measures of "strong support and hard resistance" but should

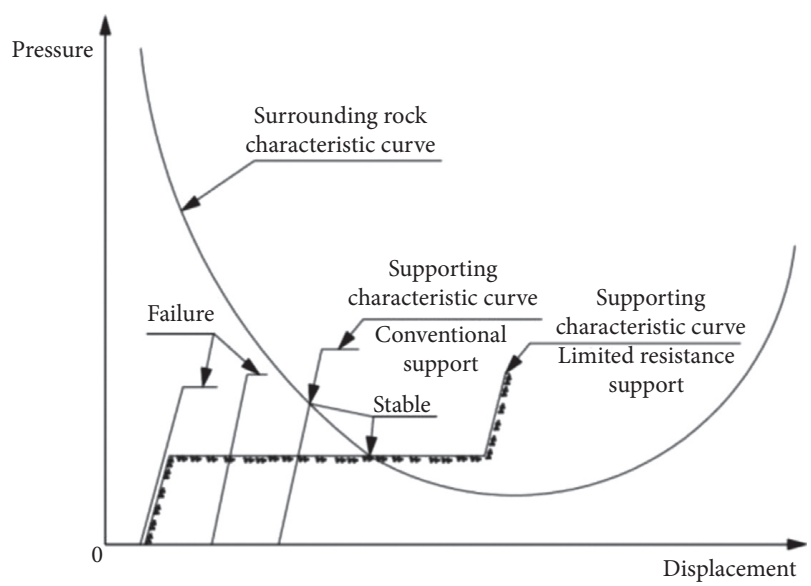

FIGURE 1: Characteristic curve of convergence-confinement.

adopt a structure that can produce a large amount of deformation and fully release the energy stored in the surrounding rock and carry out the support method of "combination of resistance and release." The use of a resistance-limiting energy-consuming support structure can limit the support resistance in the early stage and allow large deformations of the surrounding rock and support structure. In the later stage, the support resistance increases, and its support characteristic curve can finally intersect with the surrounding rock characteristic curve to achieve stability (see Figure 1).

2.2. SRLD Structure. The SRLD is composed of upper and lower connection steel plates and vertical resistance-limiting steel plates. The upper and lower connection steel plates are placed in parallel, and the vertical resistance-limiting steel plates are vertically welded on the upper and lower connection steel plates [23], as shown in Figure 2.

2.3. Working Process of SRLD. The working process of the SRLD is shown in Figure 3. A vertical pressure $P$ is applied to the connecting plate. When the pressure $P$ reaches the peak load of the vertical steel plate, the vertical steel plate begins to yield and deform until the resistance limiter is compacted.

2.4. Loading-Deformation Characteristics of SRLD. The SRLD samples were made, and the performance verification test was carried out on the universal press (see Figure 4). The typical pressure-deformation curves of the resistance limiter are shown in Figure 5.

According to the verified test results, the working period of the SRLD is mainly divided into four stages. The first stage is the elastic deformation stage, and the pressure increases linearly with the deformation. The second stage is the yield decrease stage, and the pressure decreases with the deformation. The third stage is the yield constant resistance deformation stage, and the pressure is constant with the deformation. The fourth stage is the compaction deformation stage, and the pressure increases sharply with the deformation. The third stage is the main working stage of the 


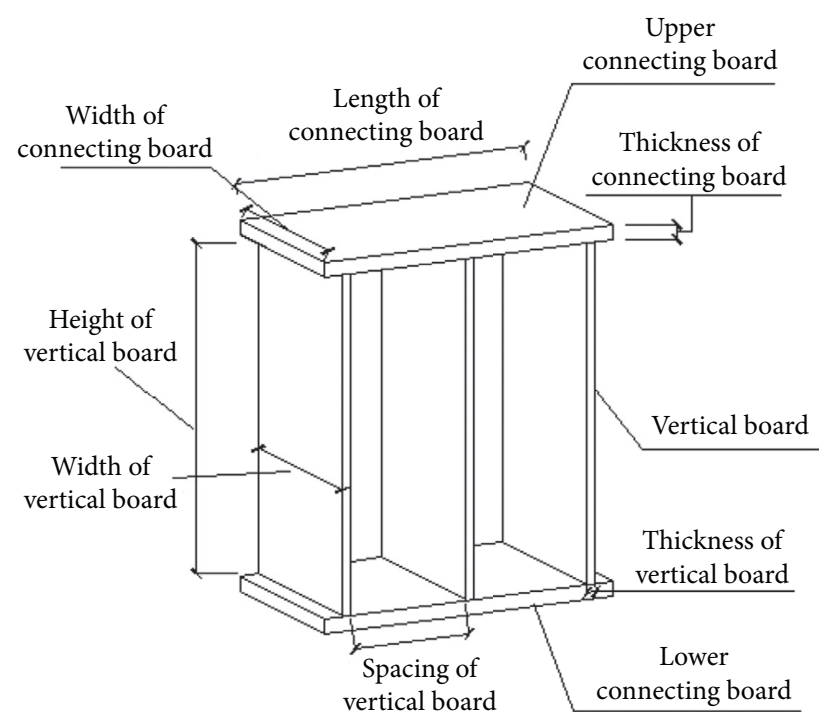

FIgURE 2: SRLD structure.

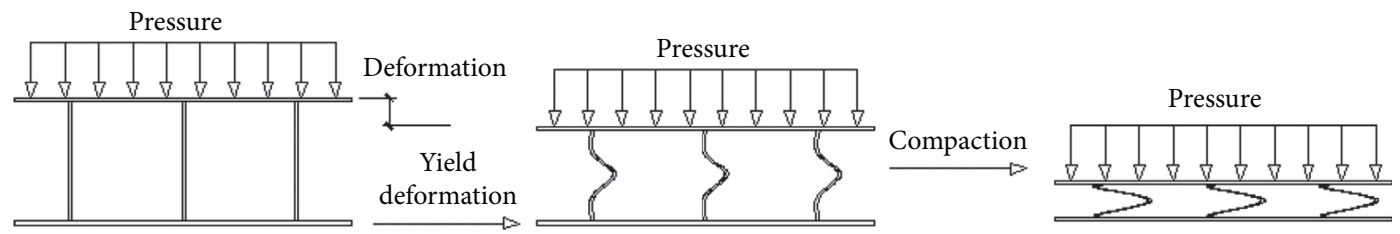

FIGURE 3: SRLD working process.

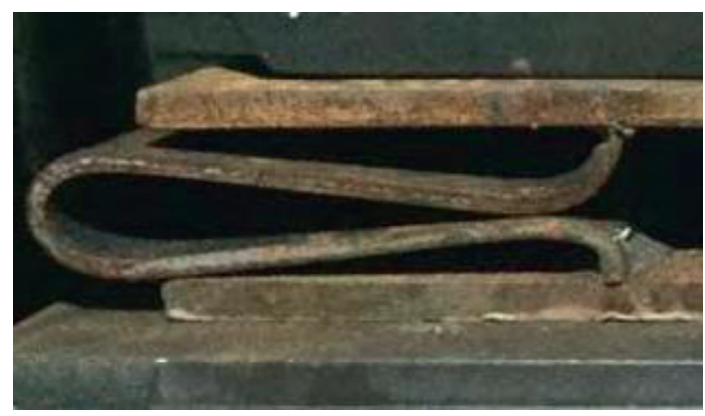

FIgURE 4: Mechanical performance test of SRLD [23].

deformation of the SRLD. The limiter undergoes largestroke deformation under the constant pressure. The pressure-deformation curve of the limiter is simplified as shown in Figure 6.

It can be seen from Figure 6 that the SRLD has high initial rigidity and a massive working stroke. At the same time, it can provide stable support resistance and can meet the requirement of guiding the surrounding rock to release energy through deformation while controlling the deformation rate of the surrounding rock. Through the on-site monitoring and measurement of the vault subsidence and clearance convergence data, the deformation rate and acceleration can be analyzed and calculated to determine whether the current support parameters are reasonable.

\section{Engineering Application of SRLD}

3.1. Engineering Overview. This paper takes the Yangshan Tunnel of the Haolebaoji-Ji'an Railway as the engineering background. The lithology of the cave in the deep-buried old loess section of this railway is the Quaternary Middle Pleistocene alluvial $\left(Q_{2}^{\mathrm{pl}}\right)$ clay old loess. The colour of the soil is brown-yellow, brown-red, brown-red, and yellow-brown. The soil is hard plastic to stern, with a small number of calcareous nodules and a large compacted structure. No groundwater was found during excavation. The plastic limit of the soil was $20 \%$, and the liquid limit was $33.4 \%$, showing soft swelling. The surrounding rock is classified as IV soil, with a burial depth of 120-140 m (see Figure 7), and the soil moisture content of the excavated face is about $15 \%$. Water seeps out after the primary branch is destroyed, and the tested soil has a water content of $20 \%$ to $23 \%$. The typical geological section of the tunnel is shown in Figure 8.

The Yangshan Tunnel is a single-hole double-line tunnel with an excavation area of $101.43 \mathrm{~m}^{2}$. It is constructed by the three-step method. The deep-buried old loess section (DK390+528 DK390+708) at the exit of the tunnel suffered damage to the primary support and caused the primary support infringement. The damage is manifested as concrete cracking and spalling at the left and right arch waist to the arch foot of the upper step, the steel 


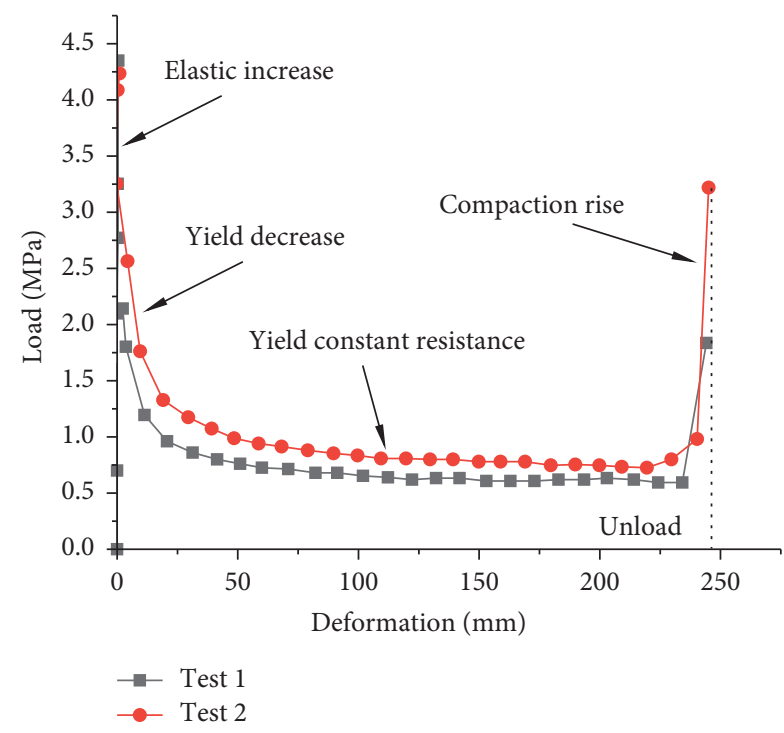

FIgURE 5: Typical loading-deformation curves of SRLD [23].

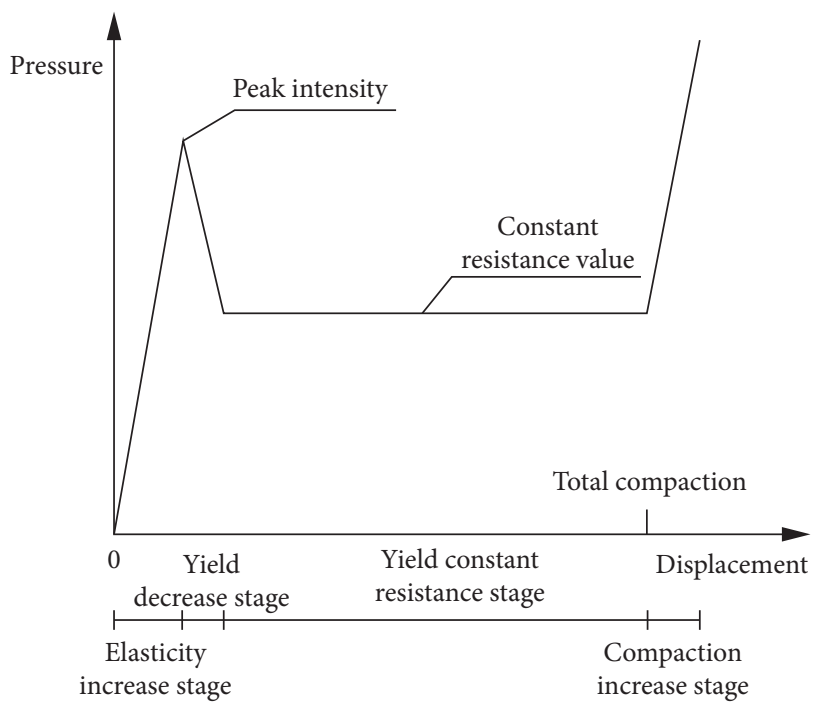

FIgURE 6: Simplified loading-deformation curve of SRLD.

frame is buckled and staggered, and the falling block runs through in the longitudinal direction. The primary support invasion limit after failure is $30-40 \mathrm{~cm}$, as shown in Figure 8.

3.2. Support Scheme of Yangshan Tunnel. In the initial construction, the designed primary support scheme (scheme I) was adopted. After the primary support of the tunnel was destroyed, the support scheme was changed to reinforced support (scheme II). The initial support failure phenomenon was significantly reduced after using reinforced support. However, concrete spalling occurred in the DK390 +462 DK390 + 467 section, indicating that the reinforced support failed to control the cracking phenomenon of the initial support fully. Therefore, an optimization scheme (scheme III) based on SRLD was designed. The specific schemes are shown in Table 1. Construction of the SRLD test is carried out in the DK390 + 152 DK390 + 168 of the Yangshan Tunnel (see Figures 9 and 10).

\subsection{Deformation Analysis of Test Sections}

3.3.1. Monitoring Scheme. According to [26], six measurement sections were laid out: DK $390+175$, DK390 + 170, DK390 + 165, DK390 + 160, DK390 + 155, and DK390 +150 . The measuring points were arranged as the vault settlement point, a horizontal line was set up and down $50 \mathrm{~cm}$ above and below the SRLD, and a horizontal line was set up $1.5 \mathrm{~m}$ above the bottom of the excavation, that is, one vault sinking measurement point and three horizontal convergence measurement lines (see Figure 11). Two measurement sections were set up on DK390 + 163 and DK390+159 to test the surrounding rock pressure. The layout of the measurement points is shown in Figure 12.

\subsubsection{Analysis of Monitoring Results}

(1) Analysis of Displacement Monitoring Results. The monitoring results are shown in Table 2 and Figure 13. For scheme II, the vault subsidence of the monitoring sections is between 20.7 and $40.9 \mathrm{~mm}$, the horizontal convergence of line 1 is between 34.2 and $106.8 \mathrm{~mm}$, the horizontal convergence of line 2 is between 27.0 and $65.0 \mathrm{~mm}$, and the horizontal convergence of line 3 is between 30.5 and $66.9 \mathrm{~mm}$. For scheme III, the vault subsidence of the sections is between 47.7 and $57.6 \mathrm{~mm}$, the horizontal convergence of line 1 is between 62.5 and $136.1 \mathrm{~mm}$, the horizontal convergence of line 2 is between 34.2 and $95.1 \mathrm{~mm}$, and the horizontal convergence of line 3 is between 30.5 and $71.4 \mathrm{~mm}$ (see Table 2). The deformation rate in the first 2 3 days after the excavation is relatively large, reaching $30 \sim 40 \mathrm{~mm} / \mathrm{d}$. The deformation tends to converge about one week after excavation. After converging for a period of time, the deformation has a weak tendency to increase (see Figure 13).

(2) Analysis of Surrounding Rock Pressure Monitoring Results. The surrounding rock pressure of the monitored section is shown in Figure 14, and the pressure distribution of the surrounding rock of each section is shown in Figure 15. The surrounding rock pressure tested on each section tends to converge in about one week (see Figure 14). The surrounding rock pressure at the arch waist is significantly higher than other locations, and the two test sections DK390 + 163 and DK390 + 159 have the highest surrounding rock pressure at the right arch waist $(0.44 \mathrm{MPa}$ and $0.51 \mathrm{MPa})$, which is consistent with the actual structure cracks.

(3) Analysis of Concrete Stress Monitoring Results. It can be seen from the figure that the measured concrete stress of each section exceeds the convergence in about one week. The concrete of the monitored section is basically in a compressed state, and the maximum compressive stress is at the inner left arch waist of the DK390+163 section 


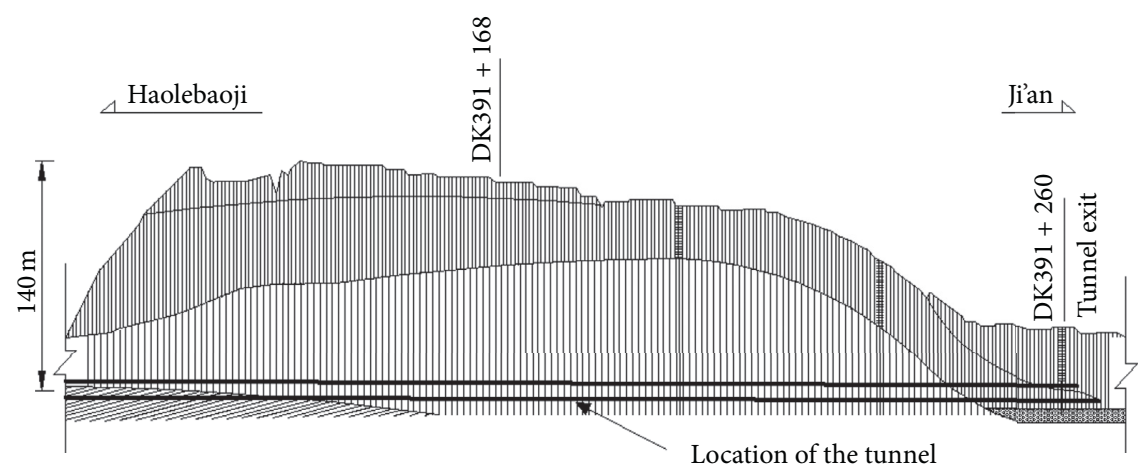

Figure 7: Typical geological section of the tunnel.

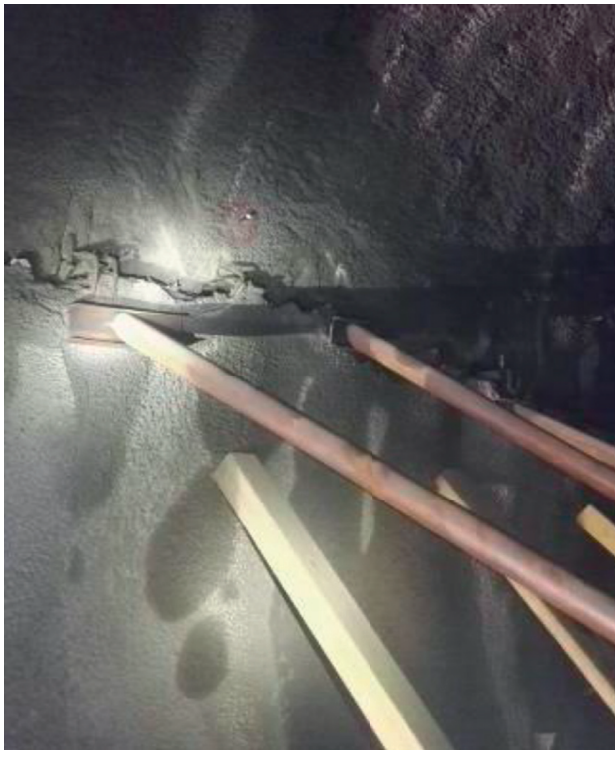

(a)

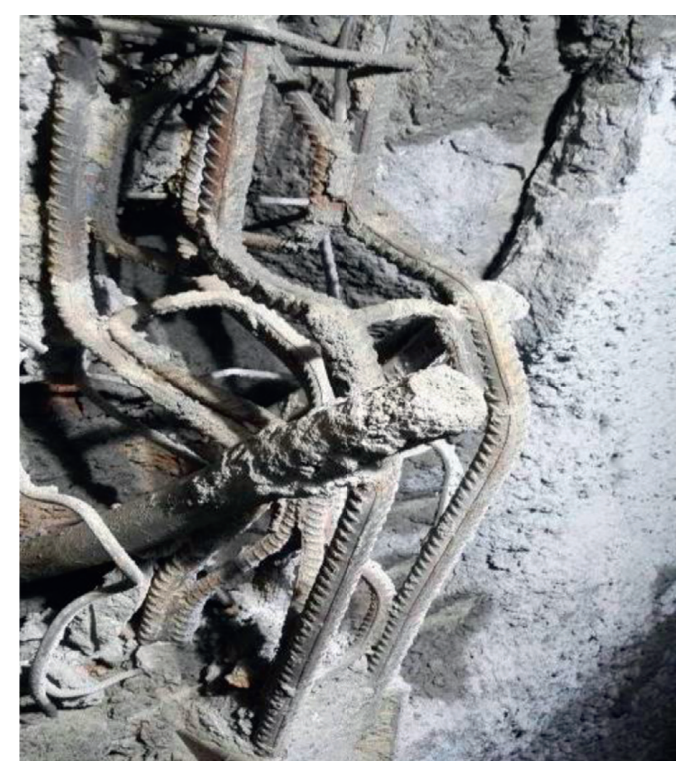

(b)

FIgURE 8: Damage of primary lining in the deep-buried loess tunnel. (a) Concrete cracking. (b) Steel frame twisted.

TABLE 1: Statistical table of displacement monitoring results.

\begin{tabular}{lccccc}
\hline Scheme & $\begin{array}{c}\text { Steel } \\
\text { frame }\end{array}$ & $\begin{array}{c}\text { Steel frame } \\
\text { spacing }(\mathrm{m})\end{array}$ & $\begin{array}{c}\text { Main rib } \\
\text { diameter }(\mathrm{mm})\end{array}$ & $\begin{array}{c}\text { C25 shotcrete } \\
\text { thickness }(\mathrm{cm})\end{array}$ & SRLD \\
\hline I & H150 & 1.0 & 22 & 22 & - \\
II & H230 & 0.6 & 28 & 30 & $\begin{array}{c}\text { Set the SRLD on the left and right arch feet of the upper step } \\
\text { (vertical steel plate thickness: } 7.5 \mathrm{~mm} \text {; height: } 28 \mathrm{~cm} \text {; spacing: } \\
\text { III }\end{array}$ \\
\hline
\end{tabular}

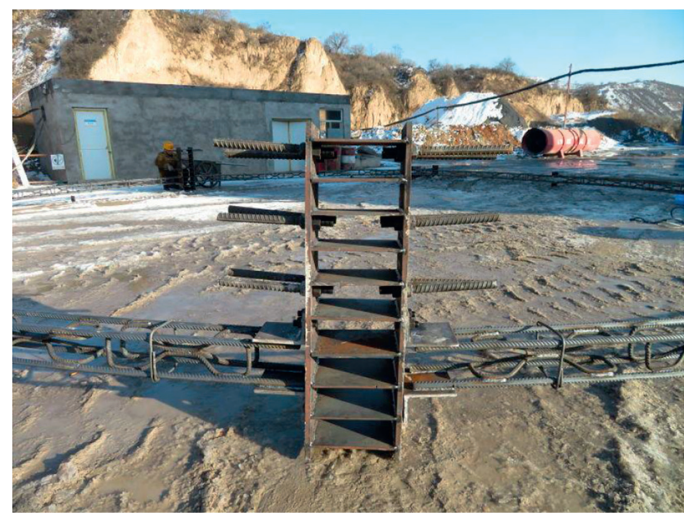

Figure 9: The assembled SRLD. 


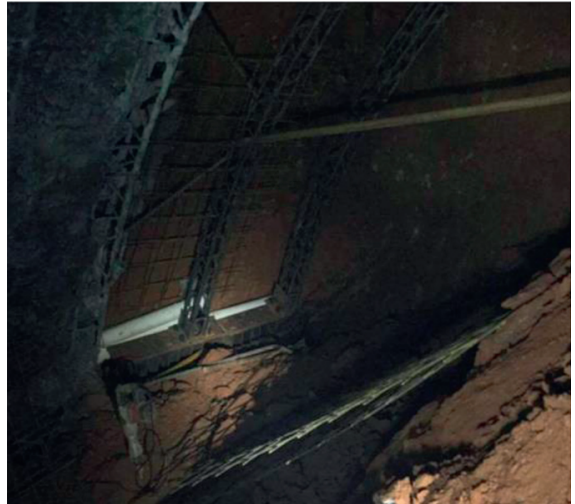

(a)

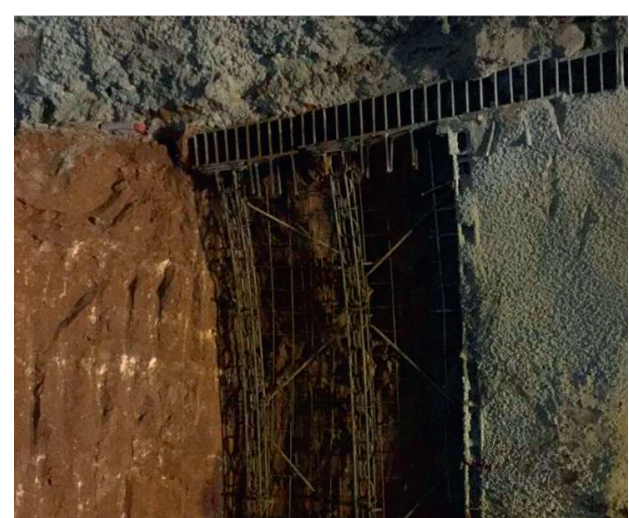

(b)

FIGURE 10: SRLD after construction. (a) Upper step. (b) Middle step.

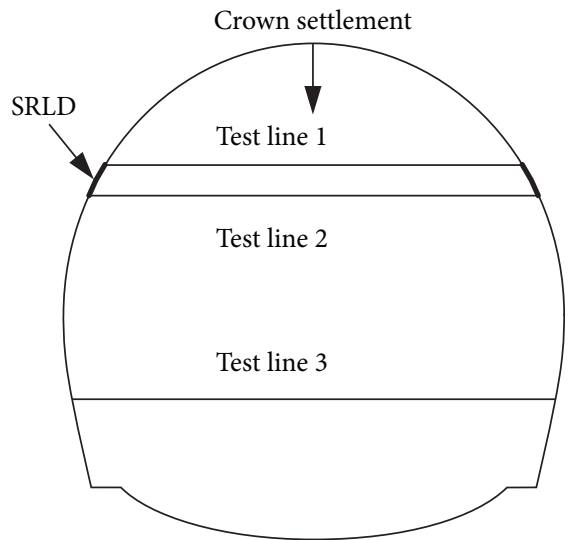

Figure 11: Diagram of crown settlement point and the horizontal convergence line.

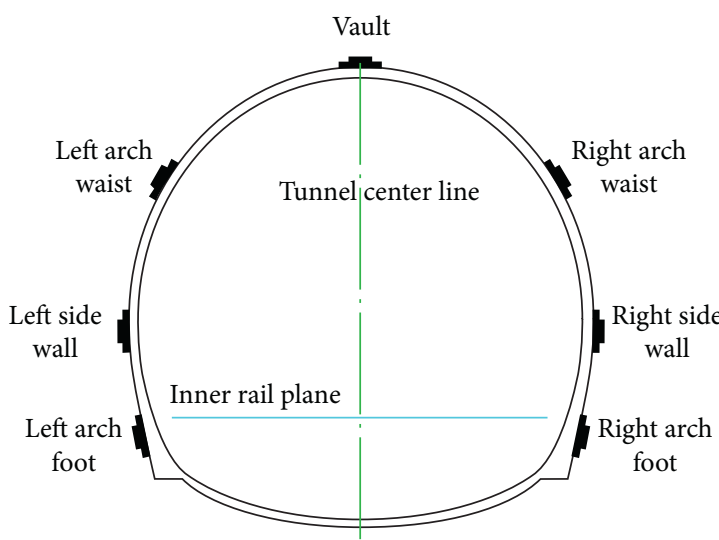

(a)

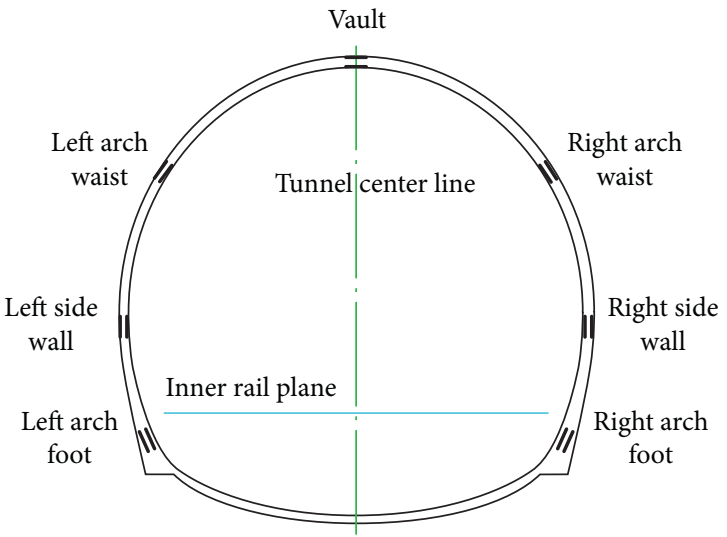

(b)

FIgURE 12: Layout of the monitoring points for internal force. (a) Surrounding rock pressure. (b) Internal stress of shotcrete.

with the value of $42.05 \mathrm{MPa}$ (see Figure 16(a)), which is consistent with the actual deformation.

About 7 to 10 days after the component is embedded, the time-history curves of the various parameters of the internal force of the structure begin to converge. Around 15 days, the surrounding rock pressure and stress deformation decreased and tended to converge gradually, indicating that the structural parameters of the test section can meet the actual needs of the project.

\section{Applicability Analysis of SRLD}

The construction progress, economy, and safety of different scheme conditions are compared, and the results are shown 
TABLE 2: Statistical table of displacement monitoring results.

\begin{tabular}{|c|c|c|c|c|c|}
\hline \multirow{2}{*}{ Mileage } & \multirow{2}{*}{ Scheme } & \multicolumn{4}{|c|}{ Cumulative deformation (mm) } \\
\hline & & Vault subsidence & Test line 1 & Test line 2 & Test line 3 \\
\hline $\mathrm{DK} 390+175$ & II & 20.7 & 66.5 & 54.8 & 50.7 \\
\hline DK390 + 170 & II & 40.9 & 106.8 & 65.0 & 66.9 \\
\hline DK390 + 165 & III & 47.7 & 77.4 & 87.0 & 67.0 \\
\hline $\mathrm{DK} 390+160$ & III & 55 & 136.1 & 95.1 & 71.4 \\
\hline DK390 + 155 & III & 57.6 & 62.5 & 34.2 & 30.5 \\
\hline $\mathrm{DK} 390+150$ & II & 21.6 & 34.2 & 42.0 & 50.1 \\
\hline
\end{tabular}

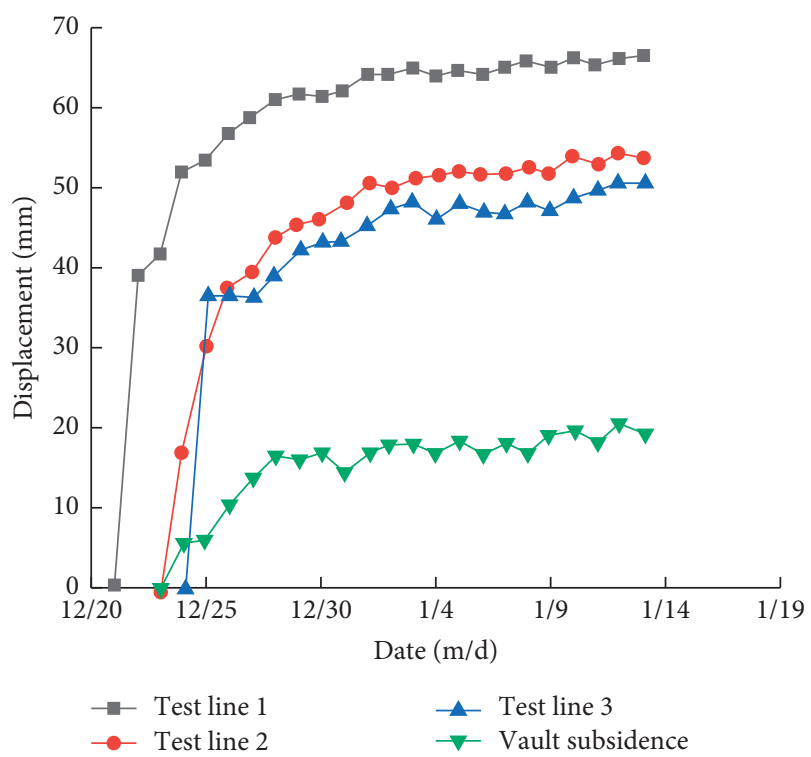

(a)

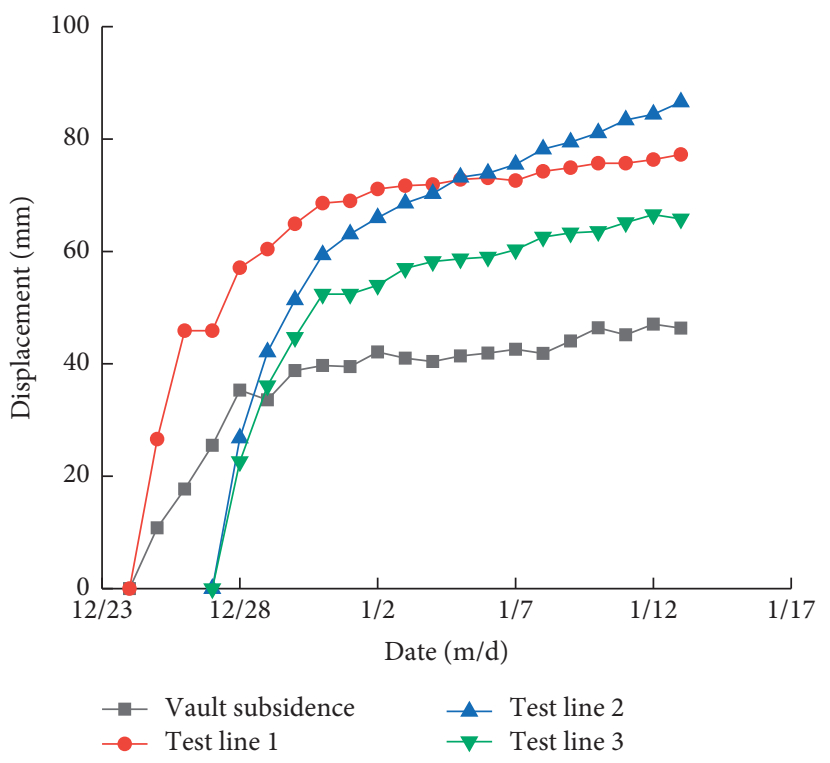

(c)

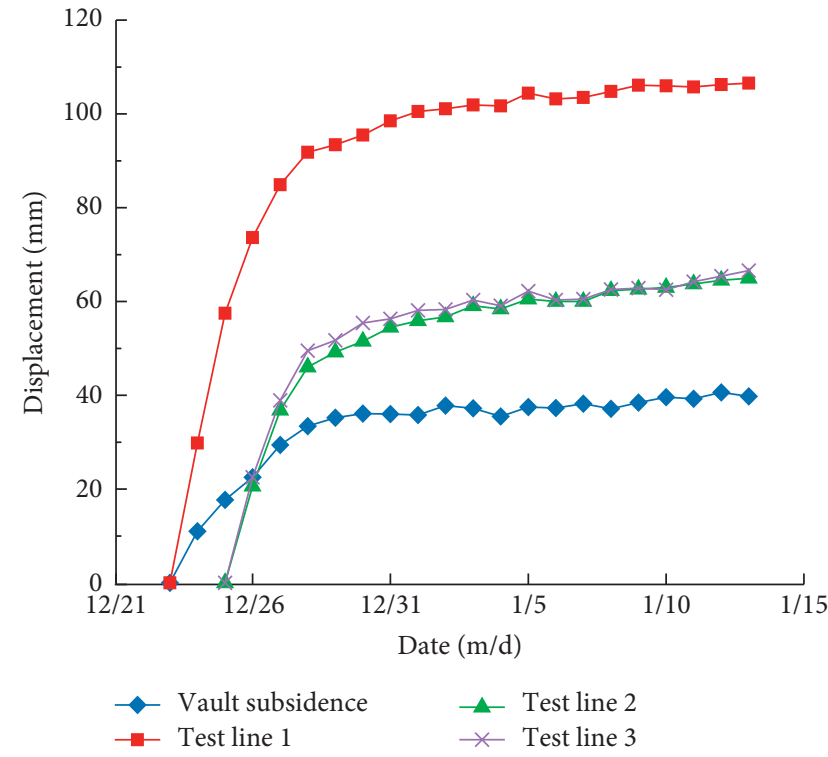

(b)

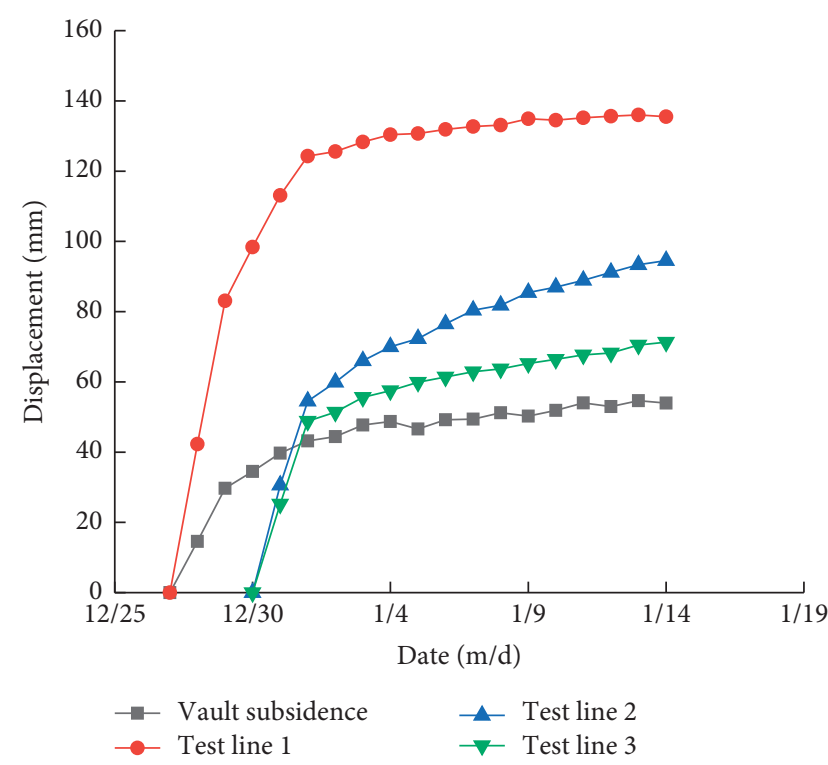

(d)

FIgURE 13: Continued. 


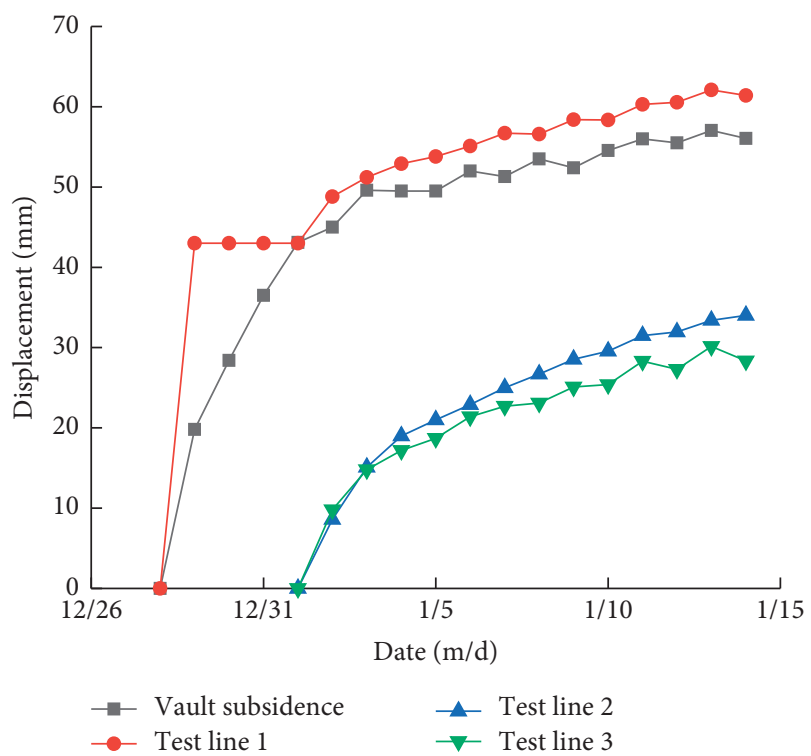

(e)

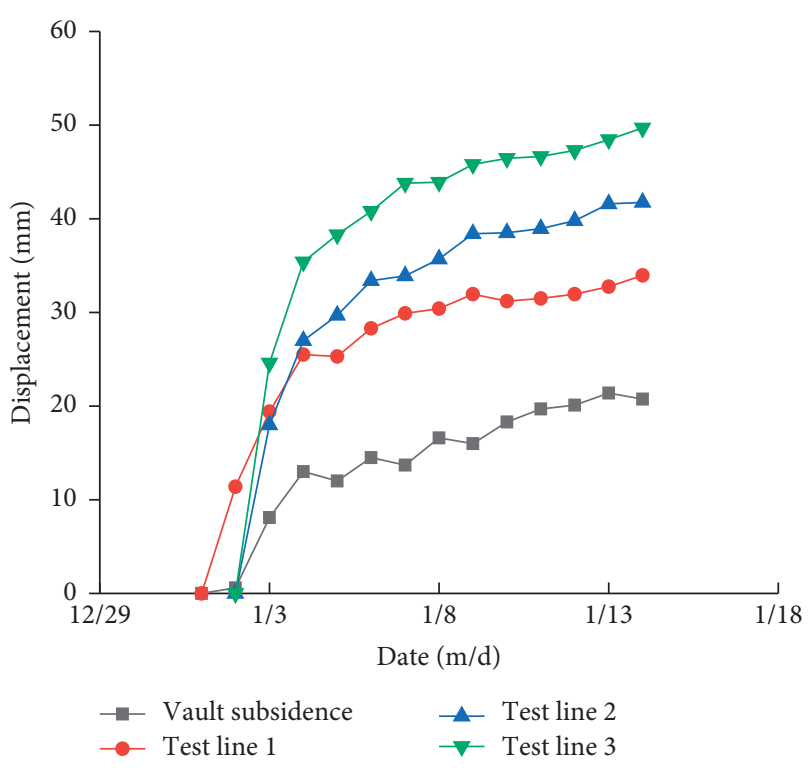

(f)

Figure 13: Time-history curves of vault subsidence and horizontal convergence. (a) DK390 + 175. (b) DK390 + 170. (c) DK390 + 165. (d) $\mathrm{DK} 390+160$. (e) DK390+155. (f) DK390+ 150 .

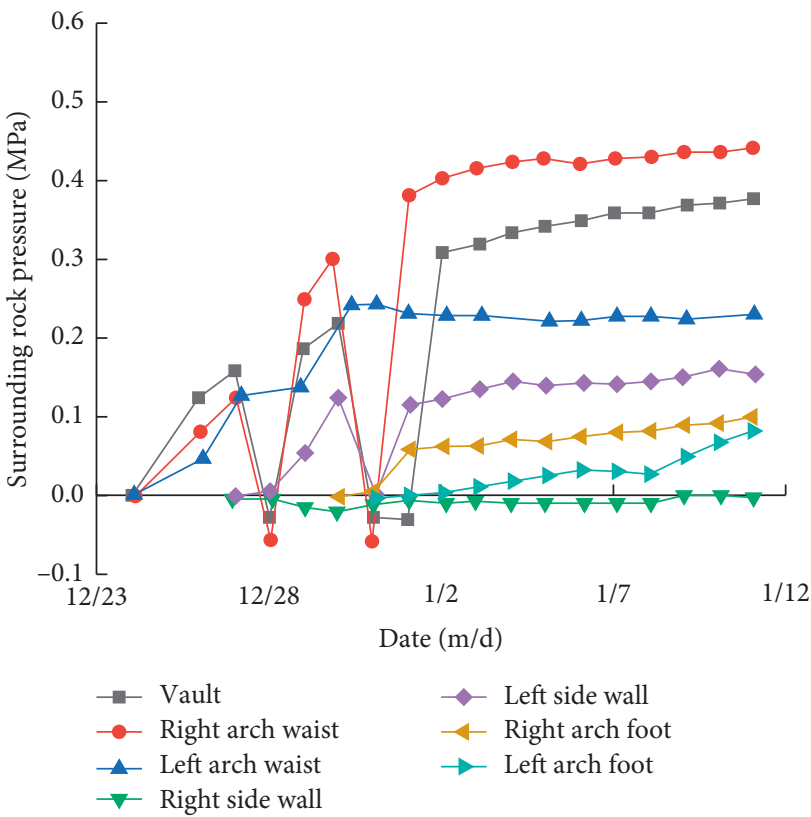

(a)

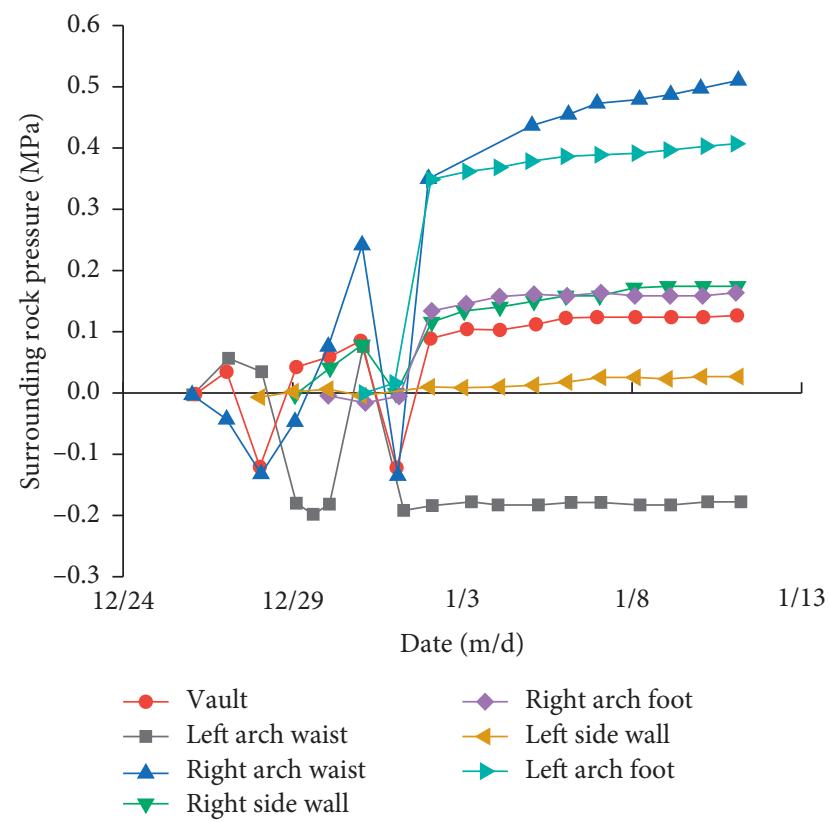

(b)

FIGURE 14: Time-history curves of surrounding rock pressure. (a) DK390 + 163. (b) DK390 + 159 .

in Tables 3-5. Under the condition that the technical proficiency is unskilled, the progress of scheme III is better than scheme II but slightly slower than scheme I (Table 3). Compared with scheme I, the amount of excavation, shotcrete, and steel mesh in scheme III increased by $0.8 \% \sim 1.6 \%$, and the amount of steel frame increased by $16.8 \%$. Compared with scheme II, the amount of excavation in scheme III is reduced by $2.5 \%$, the amount of shotcrete and steel mesh is reduced by $27 \%$, and the amount of steel frame is reduced by $47 \%$ ( Table 4). Compared with scheme I and II (Figures 8 and 17), there will be no damages such as initial support cracking and spalling, long cracks, steel frame deformation, and misalignment using scheme III (Figure 18).

From the aspects of the economy, construction progress, and safety, the SRLD scheme is better than the other two 


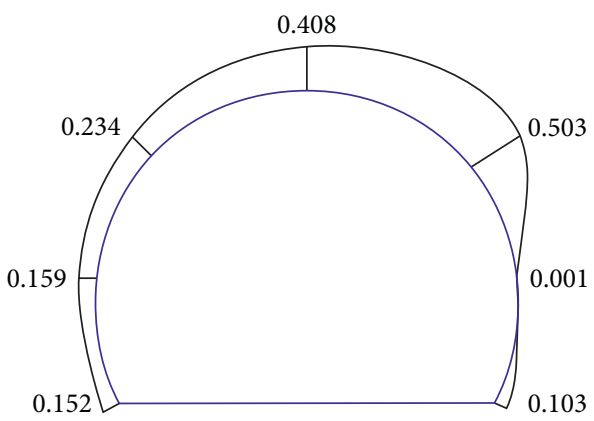

(a)

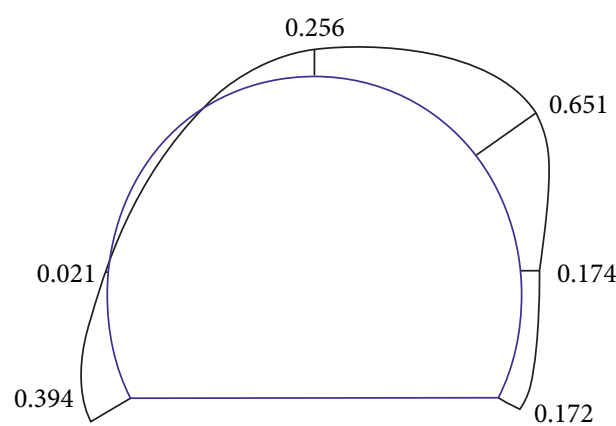

(b)

FIGURE 15: Circumferential distribution of surrounding rock pressure. (a) DK390 + 163. (b) DK390 + 159 .

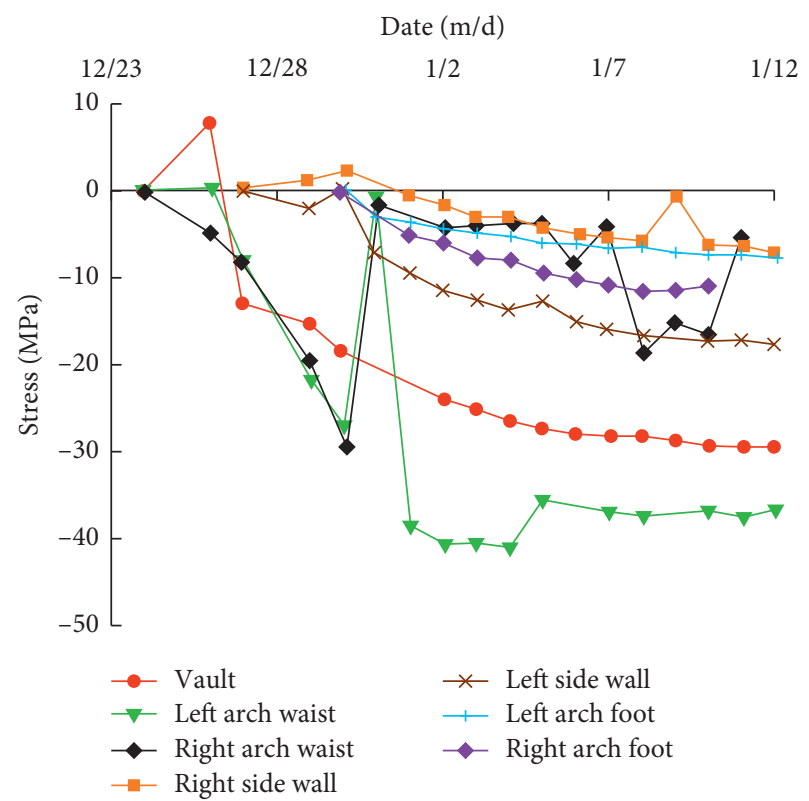

(a)

Date $(\mathrm{m} / \mathrm{d})$

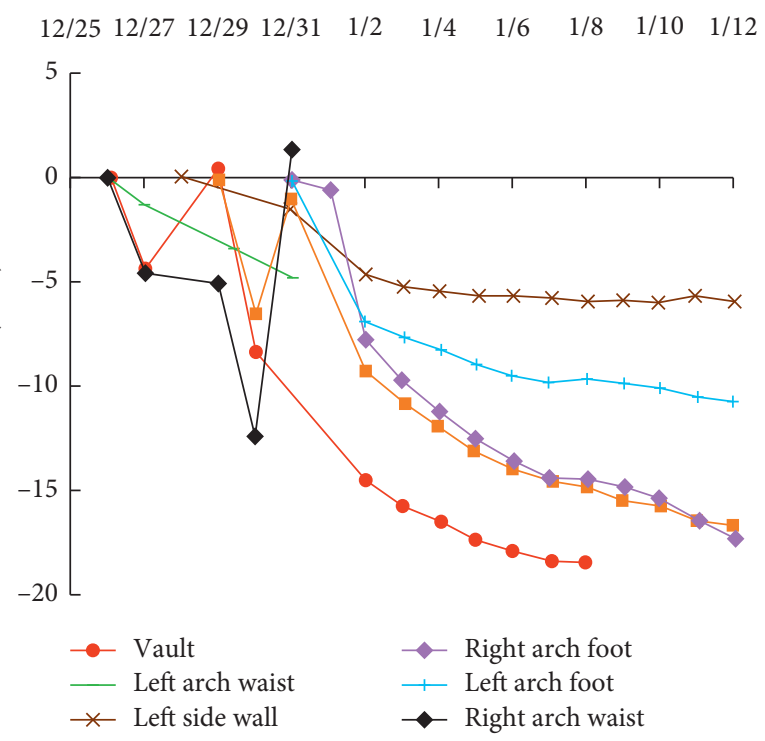

(c)

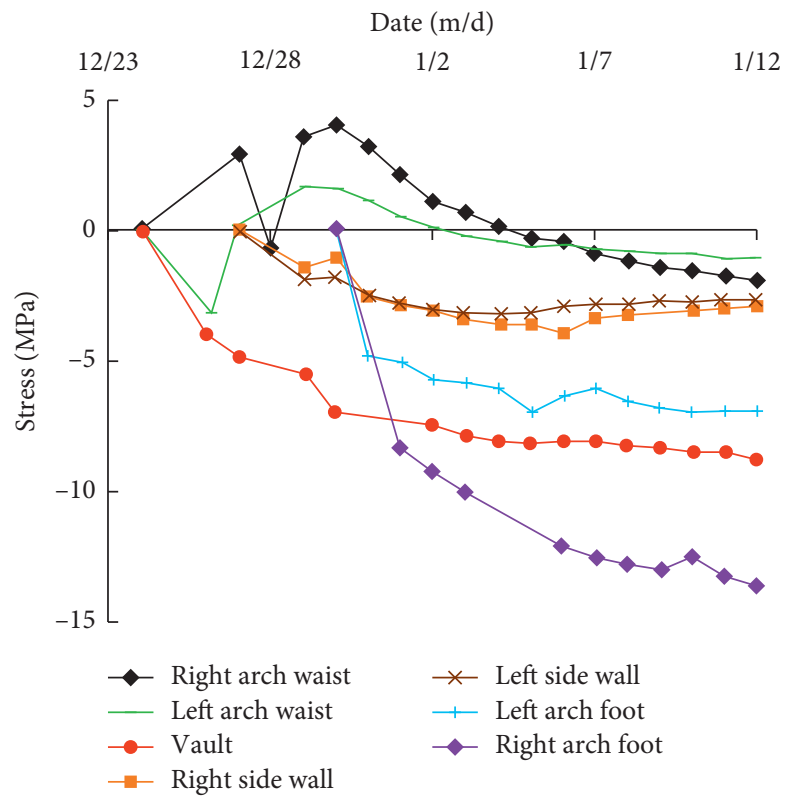

(b)

Date $(\mathrm{m} / \mathrm{d})$

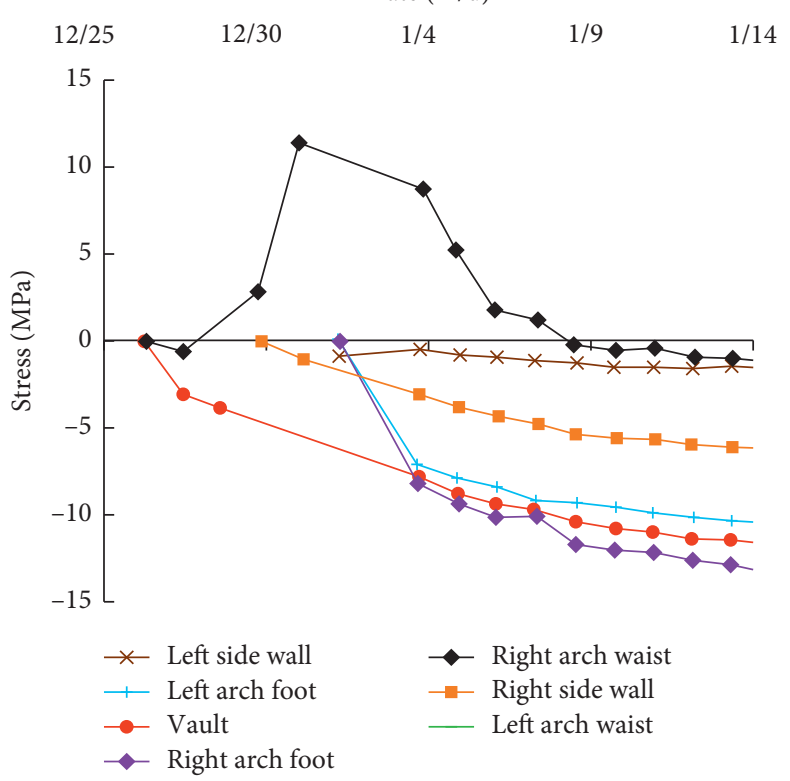

(d)

FIgURE 16: Time-history curves of concrete stress. (a) DK390+163 inside. (b) DK390+163 outside. (c) DK390+159 inside. (d) DK390 + 159 outside. 
TABLE 3: Construction progress comparison table.

\begin{tabular}{|c|c|c|c|c|c|}
\hline Scheme & Construction time (days) & Mileage & Tunneling length $(\mathrm{m})$ & Progress rate $(\mathrm{m} / \mathrm{d})$ & Process proficiency \\
\hline I & 149 & $\mathrm{DK} 390+960 \sim+520$ & 440 & 4.0 & Very skilled \\
\hline II & 140 & DK390 + 520 +168 & 352 & 2.4 & Skilled \\
\hline III & 5 & DK390 + 168 +152 & 16 & 3.2 & Unskilled \\
\hline
\end{tabular}

TABle 4: Engineering quantity comparison table.

\begin{tabular}{lcccccc}
\hline \multirow{2}{*}{ Project unit } & \multicolumn{3}{c}{ Quantity comparison } & \multirow{2}{*}{ Scheme III/scheme I (\%) } & \multirow{2}{*}{ Scheme III/scheme II (\%) } \\
\hline Soil and rock excavation & $\mathrm{m}^{3}$ & 101.44 & 105.69 & 103.04 & 101.6 & 97.5 \\
C25 shotcrete & $\mathrm{m}^{3}$ & 8.43 & 11.62 & 8.50 & 100.8 & 73.1 \\
Steel mesh & $\mathrm{kg}$ & 105.95 & 146.87 & 106.78 & 100.8 & 72.7 \\
Steel used for steel frame & $\mathrm{kg}$ & 1036.80 & 2297.54 & 1211.42 & 116.8 & 52.7 \\
Steel frame spacing & $\mathrm{m}$ & 1.00 & 0.60 & 1.00 & - & - \\
\hline
\end{tabular}

TABLE 5: Safety comparison table.

\begin{tabular}{|c|c|c|c|c|}
\hline Scheme & Mileage & Cracked or not & Cause of cracking & Structural safety \\
\hline I & DK390 + 786 DK390 + 520 & $\begin{array}{l}\text { Along the longitudinal direction } \\
\text { of the tunnel, a continuous } \\
\text { crack and dislocation of about } \\
180 \mathrm{~m} \text { occurred on the left and } \\
\text { right arch waist }\end{array}$ & $\begin{array}{l}\text { On the action of surrounding } \\
\text { rock pressure, the primary } \\
\text { support at the arch waist bears } \\
\text { great hoop stress, and the } \\
\text { structure is compressed, and } \\
\text { shear failure occurs }\end{array}$ & $\begin{array}{c}\text { Both the left and right arches } \\
\text { were damaged, and the } \\
\text { structure is unsafe }\end{array}$ \\
\hline II & DK390 + 520 DK390 + 168 & $\begin{array}{l}\text { The left and right arches are easy } \\
\text { to produce diagonal cracks and } \\
\text { longitudinal cracks of about } 1 \mathrm{~m} \\
\text { in length }\end{array}$ & $\begin{array}{l}\text { Changing the scheme increases } \\
\text { the rigidity of the structure, but } \\
\text { the internal force of the } \\
\text { structure increases. Once the } \\
\text { internal force of the structure is } \\
\text { greater than the ultimate } \\
\text { strength of the material, the } \\
\text { structure will crack }\end{array}$ & $\begin{array}{c}\text { Cracking, peeling, and falling } \\
\text { pieces occur at the arch waist, } \\
\text { and the structural safety is } \\
\text { insufficient }\end{array}$ \\
\hline III & DK390 + 168 DK390 + 152 & $\begin{array}{l}\text { Longitudinal cracks above the } \\
\text { SRLD }\end{array}$ & $\begin{array}{c}\text { The weak surface formed by the } \\
\text { shotcrete above the SRLD is } \\
\text { easy to crack and peel off }\end{array}$ & $\begin{array}{l}\text { The vertical steel plate of the } \\
\text { SRLD deforms and only } \\
\text { accounts for about } 10 \% \text {, and the } \\
\text { amount of deformation is less } \\
\text { than } 10 \% \text { of the design estimate, } \\
\text { and the structure is safe }\end{array}$ \\
\hline
\end{tabular}

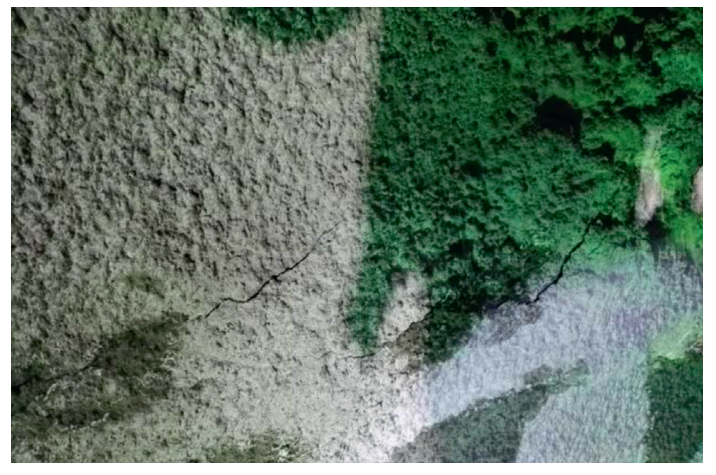

(a)

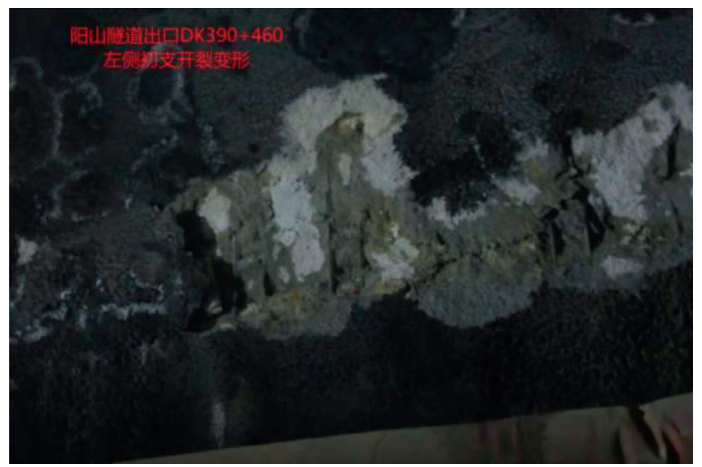

(b)

FIGURE 17: Primary support cracking and spalling (scheme II). 


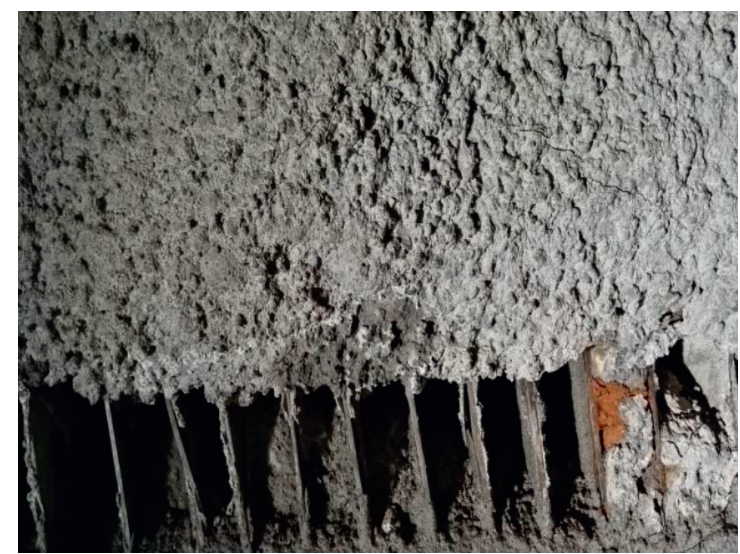

FIgURE 18: Primary support cracking (scheme III).

schemes, and the SRLD scheme is worthy of promotion and application.

\section{Conclusions}

(1) The traditional rigid support allows small deformation and releases less energy from the surrounding rock. It is challenging to solve the problem of support failure during the construction of deep-buried large-section loess tunnels. When dealing with geological problems such as large deformation of loess tunnels, the design concept should be changed from a large rigidity and strong support method to a limited resistance and release energy support method that allows the deformation of the surrounding rock and controls its energy release.

(2) Embedding the SRLD into the primary support can transform the traditional rigid support into a limited resistance and energy release support. By setting the SRLD in the essential force-bearing parts, the final deformation of the surrounding rock is significantly increased and the problem of primary support cracking can be effectively solved. It shows that the SRLD can limit the internal force of the structure and release the surrounding rock pressure in a controllable manner. It is a feasible and effective way of supporting deep-buried large-section loess tunnels.

(3) The surrounding rock deformation of the experimental section tends to converge about one week after excavation, indicating that the support-surrounding rock system of the SRLD scheme can quickly reach a stable state. The maximum value of surrounding rock pressure and internal structural force occurred at the arch waist. From the comprehensive comparison and analysis of the economy, construction process, and safety, it can be seen that the construction plan of the SRLD support is worthy of popularizing and using.

\section{Data Availability}

The data included in this study are available from the corresponding author upon request.

\section{Conflicts of Interest}

The authors declare that they have no conflicts of interest.

\section{Acknowledgments}

The author would like to thank the National Key R\&D Program of China (2018YFC0808701), China Postdoctoral Science Foundation (2020M673525), and China Railway 20th Bureau Group Co. Ltd. (YF2000SD01A).

\section{References}

[1] M. Bayati and J. Khademi Hamidi, "A case study on TBM tunnelling in fault zones and lessons learned from ground improvement," Tunnelling and Underground Space Technology, vol. 63, pp. 162-170, 2017.

[2] S. Wang, C. Li, Z. Liu, and J. Fang, "Optimization of construction scheme and supporting technology for HJS soft rock tunnel," International Journal of Mining Science and Technology, vol. 24, no. 6, pp. 847-852, 2014.

[3] W. Yu, W. Wang, X. Chen, and S. Du, "Field investigations of high stress soft surrounding rocks and deformation control," Journal of Rock Mechanics and Geotechnical Engineering, vol. 7, no. 4, pp. 421-433, 2015.

[4] M. Sharifzadeh, F. Kolivand, M. Ghorbani, and S. Yasrobi, "Design of sequential excavation method for large span urban tunnels in soft ground-Niayesh tunnel," Tunnelling and Underground Space Technology, vol. 35, pp. 178-188, 2013.

[5] I. Jefferson, N. Mavlyanova, K. O'Hara-Dhand, and I. Smalley, "The engineering geology of loess ground: 15 tasks for investigators-the Mavlyanov programme of loess research," Engineering Geology, vol. 74, no. 1-2, pp. 33-37, 2004.

[6] J. Qiu, X. Wang, J. Lai, Q. Zhang, and J. Wang, "Response characteristics and preventions for seismic subsidence of loess in Northwest China," Natural Hazards, vol. 92, no. 3, pp. 1909-1935, 2018.

[7] P. Li, Y. Zhao, and X. Zhou, "Displacement characteristics of high-speed railway tunnel construction in loess ground by using multi-step excavation method," Tunnelling and Underground Space Technology, vol. 51, pp. 41-55, 2016.

[8] Y. Xue, X. Zhang, S. Li et al., "Analysis of factors influencing tunnel deformation in loess deposits by data mining: a deformation prediction model," Engineering Geology, vol. 232, pp. 94-103, 2018.

[9] K. Kovári, "Tunnelling in squeezing rock," Rock Mechanics and Rock Engineering, vol. 29, no. 3, p. 111, 1996.

[10] G. Anagnostou and L. Cantieni, "Design and analysis of yielding support in squeezing ground," in Proceedings of the 11th International Society for Rock Mechanics and Rock Engineering (ISRM) Congress, Lisbon, Portugal, July 2007.

[11] W. Schubert, "Dealing with squeezing conditions in Alpine tunnels," Rock Mechanics and Rock Engineering, vol. 29, no. 3, pp. 145-153, 1996.

[12] K. Kovári, "Design methods with yielding support in squeezing and swelling rocks," in Proceedings of the World Tunnel Congress Ed., pp. 1-10, Budapest, Hungary, May 2009.

[13] A. Thut, D. Naterop, P. Steiner, and M. Stolz, "Tunnelling in squeezing rock-yielding elements and face control," in Proceedings of the 8th International Symposium on Tunnel Construction and Underground Structures Ed., Lubljana, Slovenia, November 2006.

[14] L. Cantieni and G. Anagnostou, "The interaction between yielding supports and squeezing ground," Tunnelling and 
Underground Space Technology, vol. 24, no. 3, pp. 309-322, 2009.

[15] G. Barla, M. Bonini, and M. Semeraro, "Performance monitoring and analysis of a yieldontrol support system in squeezing rock," in Rock Mechanics in Civil and Environmental Engineering, J. Zhao, V. Labiouse, J. P. Dudt, and J. F. Mathier, Eds., pp. 459-462, Taylor \& Francis Group, London, UK, 2010.

[16] G. Barla, M. Bonini, and M. Semeraro, "Analysis of the behaviour of a yield-control support system in squeezing rock," Tunnelling and Underground Space Technology, vol. 26, no. 1, pp. 146-154, 2011.

[17] K. Wu and Z. Shao, "Study on the effect of flexible layer on support structures of tunnel excavated in viscoelastic rocks," Journal of Engineering Mechanics, vol. 145, no. 10, Article ID 04019077, 2019.

[18] K. Wu and Z. Shao, "Visco-elastic analysis on the effect of flexible layer on mechanical behavior of tunnels," International Journal of Applied Mechanics, vol. 11, no. 3, Article ID 1950027, 2019.

[19] K. Wu, Z. Shao, and S. Qin, "An analytical design method for ductile support structures in squeezing tunnels," Archives of Civil and Mechanical Engineering, vol. 20, no. 3, pp. 1-13, 2020.

[20] K. Wu, Z. Shao, S. Qin, N. Zhao, and H. Hu, "Analytical-based assessment of effect of highly deformable elements on tunnel lining within viscoelastic rocks," International Journal of Applied Mechanics, vol. 12, no. 3, Article ID 2050030, 2020.

[21] J. Sun, X. Pan, and Y. Wang, "Study on non linear rheologic mechanical property of squeezing deformation of soft surrounding rock in tunneling and its anchorage mechanism," Tunnel Construction, vol. 35, no. 10, p. 969, 2015.

[22] B. Wang, J. Wang, and $\mathrm{D}$. Wu, "Study of application of yielding supporting system for large deformation in soft rock highway tunnel," Journal of Railway Science and Engineering, vol. 13, no. 10, p. 1985, 2016.

[23] W. Qiu, G. Wang, and L. Gong, "Research and application of resistance-limiting and energy-dissipating support in large deformation tunnel," Chinese Journal of Rock Mechanics and Engineering, vol. 37, no. 8, pp. 1786-1795, 2018.

[24] M. Huang, J. Zhao, and Z. Tao, "Analysis of the deformation and mechanical characteristics of the surrounding rock-lining structure of the Muzhailing tunnel," Modern Tunnelling Technology, vol. 53, no. 6, p. 89, 2016.

[25] C. B. He and L. H. Shu, "Deformation mechanization and construction control of high ground stresses soft rock tunnel in Lanzhou-Chongqing railway," Journal of Railway Engineering Society, vol. 31, no. 5, pp. 68-73, 2014.

[26] Q/CR 9218-2015, Technical Specification for Monitoring Measurement of Railway Tunnel, China Railway Publishing House, Beijing, China, 2015. 